\title{
EFFECT OF IODINE DEFICIENCY ON THE REPRODUCTIVE PERFORMANCE OF FEMALE RATS AND THE VIABILITY AND GROWTH RATE OF THEIR PROGENY
}

\author{
Vappu Kossila and Ritva MyllymaA \\ Department of Animal Husbandry, University of Helsinki
}

Received January 10, 1970

Iodine deficiency and goitrogenic substances in the diet have been reported to decrease the reproductivity of sheep (FLux et al. 1960) and hen (Rogler 1958, Rogler et al. 1959). Thyroidectomy of pregnant sheep (FALCONER 1965) and goats (EKMAN 1965) reduced severely the viability of the new-born. In rats, thyroidectomy decreased the ovarian function (Evans et al. 1960). Thyroactive substances, in turn, increase the weight of the ovaries and uterus in mice (Solrman \& REINEKE 1952), the ovarian responsiveness to equine gonadotrophin in rats and mice (Johnson \& Mertes 1950), the response of the uterus to oestradiol in rabbits (VAEs 1960), and the fertility of sheep (HART 1960, Ryle 1961) and cows (TurNER 1959).

In larger farm animals iodine deficiency causes reproductive failures primarily through development of a goitrous condition in the fetus (GUILBERT 1942). In rat, however, storage of $\mathrm{I}^{131}$ (Gorbman \& Evans 1941) and follicular differentiation (Gorbman 1955) of the fetal thyroid begins on the 19th day of gestation, which is comparatively much later than in some larger species. Once initiated, the differentiation may be speeded up by TSH (SETHRE \& WELLS 1951). The goitrogenic action on the fetus of thiouracil given to mother is seen only after follicular differentiation of the fetal thyroid has occurred (LOGoTHETopoulos \& ScotT 1956). Thus it is uncertain, whether iodine deficiency or goitrogens in the diet of the mother rat have time to act on the fetal thyroid before the birth of the pups.

In experimental conditions thyroid insufficiency can be induced, among others, by thyroidectomy, by feeding goitrogenic substances like thiouracil, or by feeding an iodine deficient diet to the animals. In thyroidectomized or thiouracil treated rats, however, a high iodine diet or thyroxine analoques possessing no iodine may be thyromimetic (HsIEH 1962, Asling \& Evans 1963, Griesbach et al. 1963, Jorgensen \& Wiley 1963). Furthermore, thiouracil and a number of other goitrogens have exhathyroidal effects (GAUNT et al. 
1965), and although a goitrous condition can be induced rapidly in animals with goitrogens (Shultze \& Turner 1947, p. 33), the resulting physiological condition is apparently not identical with that induced merely by a simple iodine deficiency.

Iodine deficiency can be easily induced in experimental animals by limiting the iodine intake while simultaneously increasing the calcium content of the diet (Thompson 1933). An excess of calcium may limit, however, in addition to the iodine, also the utilization of other elements essential or beneficial for the reproductional functions (ref. LAmming 1966, p. 9).

The present study was designed in order to find out whether the shortage of iodine alone reduced the reproductive performance of female rats, and the viability, growth rate, and fertility of their progeny when fed with a diet balanced in respect of other nutrients.

Table 1. Composition of the diets used during the experiment.

Semisynthetic diet

$\begin{array}{lr}\text { Basic components } & \% \\ \text { Casein } & 30 \\ \text { Glucose } & 54 \\ \text { Sesam oil } & 10 \\ \text { Ground cellulose } & 2 \\ \text { Mineral salt mixture } & 4 \\ & \\ \text { Mineral salt mixture } & \% \\ & \\ \mathrm{CaCO} & 6.860 \\ \mathrm{Ca}-\mathrm{citrate}_{4} & 30.830 \\ \mathrm{CaHPO} & 11.280 \\ \mathrm{~K}_{2} \mathrm{HPO}_{4} \cdot 2 \mathrm{H}_{2} \mathrm{O} & 21.880 \\ \mathrm{KCl} & 12.470 \\ \mathrm{NaCl} & 7.710 \\ \mathrm{MgSO}_{4} \text { sicc. } & 3.830 \\ \mathrm{MgCO}_{3} & 3.520 \\ \mathrm{Fe}(\mathrm{III}) \text { amm. citrate } & 1.526 \\ \mathrm{MnSO}_{4} \cdot \mathrm{H}_{2} \mathrm{O} & 0.020 \\ \mathrm{CuSO} & 0.008 \\ \left.\mathrm{KI}^{1}\right) & 0.004 \\ \mathrm{NaF}_{2} \mathrm{O} & 0.050 \\ \mathrm{AlNH}_{4}\left(\mathrm{SO}_{4}\right)_{2} \cdot 12 \mathrm{H}_{2} \mathrm{O} & 0.009\end{array}$

Vitamins per $1 \mathrm{~kg}$ feed

$\beta$-carotene
Calciferol
Vit. E. acetate
Thiamine - HCl
Riboflavin
Pyridoxine
Ca-pantothenate
Niacin
Inositol
Choline
p-amino benzoic acid
Folic acid ${ }^{2}$ )
Biotin ${ }^{2}$ )

Commercial diet ${ }^{3}$ )

$\begin{array}{lc}\text { Basic components } & \% \\ \text { Oats } & 22 \\ \text { Wheat } & 11 \\ \text { Barley } & 12 \\ \text { Wheat germ } & 5 \\ \text { Soya meal } & 10 \\ \text { Fish " } & 10 \\ \text { Whale " } & 6 \\ \text { Grass " } & 3 \\ \text { Bone " } & 3.6 \\ \text { Brewer's yeast } & 2.0 \\ \text { Milk powder, fat-free } & 7.0 \\ \text { " " with fat } & 6.0 \\ \text { Corn oil } & 1.0 \\ \text { Minerals + vitamins } & 0.4\end{array}$

Minerals $\&$ vitamins per $100 \mathrm{~kg}$ diet

Vitamin A

"
$\mathrm{D}_{3}$

Folic acid

Thiamine

Riboflavin

Niacin

Ca-pantothenate

Choline

$\mathrm{NaCl}$

$\mathrm{FeSO}_{4}$

$\mathrm{MgSO}_{4}$

$\mathrm{MnSO}_{4}$

$\mathrm{CuSO}_{4}$

$\mathrm{ZnSO}_{4}$

Iodine

$\mathrm{CoSO}_{4}$
6.5 mill.I.U.

$8 \mathrm{~g}$ 240000 I.U.

$0.05 \mathrm{~g}$

0.20 "

0.40 "

2 "

$1 "$

10 "

200 "

50 "

30 "

10 "

0.1 "

$1.0 "$

0.1 "

0.1 "

1) KI was excluded from the iodine deficient diet.

${ }^{2}$ ) These vitamins were added into the diet at the beginning of Experiment II.

s) Mankkaa's Mouse and Rat Diet. 


\section{Material and methods}

D i e t. The compositon of the semisynthetic diet (control and iodine deficient) (ref. RAUEN 1964) as well as the commercial mouse and rat diet used in this study are given in
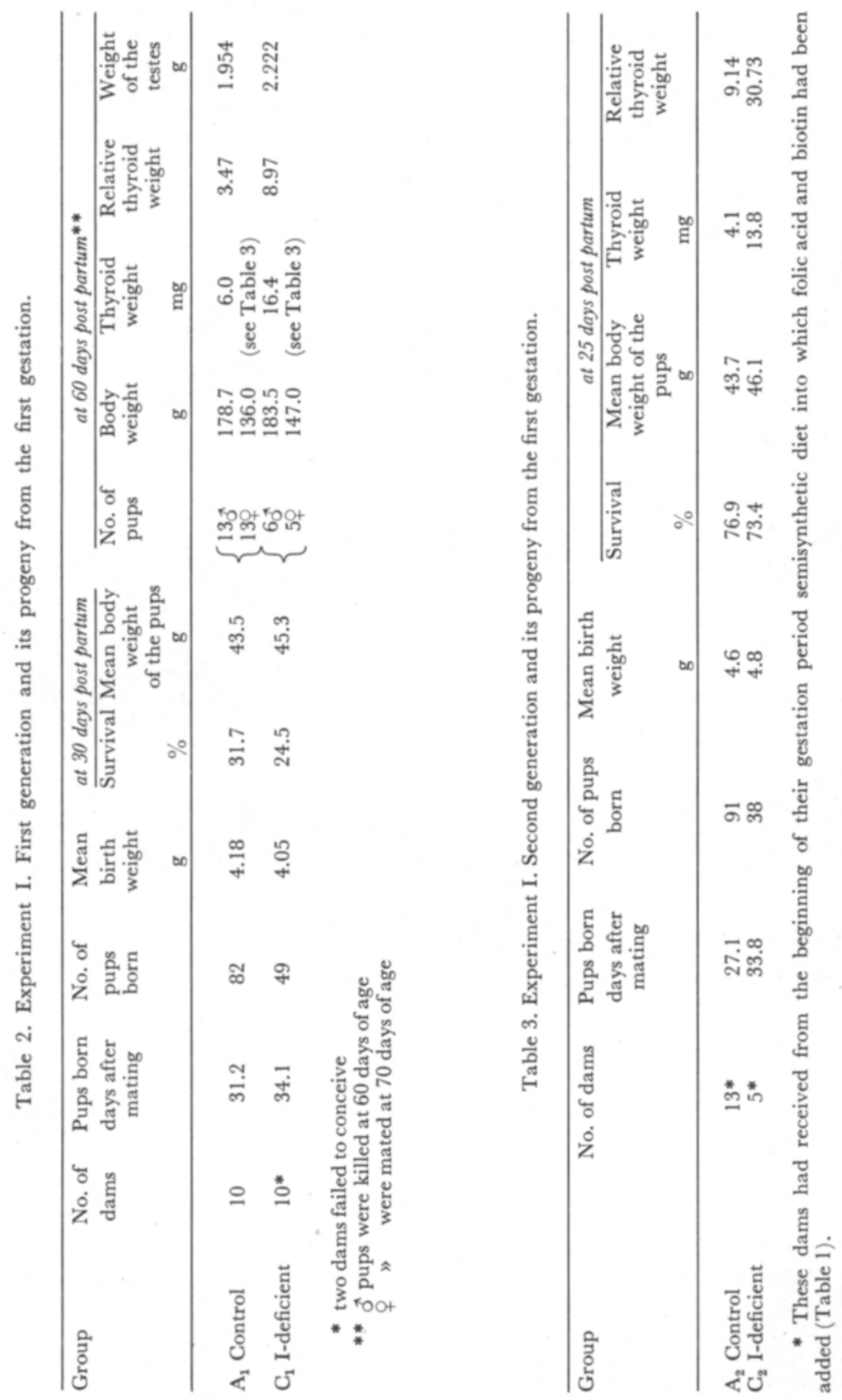
Table 1. When a sample of the iodine deficient diet was analyzed in the laboratory of the State Agricultural Chemistry, Helsinki, no iodine was found. SEPPÄnEN (1969) noted that small amounts of folic acid and biotin were beneficial for the growth of rats, these two vitamins were added into the semipurified diet at the beginning of Experiment II, although also second generation rats in Experiment I (Table 3) received these vitamins.

B lood a n a lys es. Blood was drawn from the heart of anesthetized adult $q$ rats this treatment leading to the death of the rats. Blood hematocrit $(\mathrm{Hc})$ values were determined by the microcapillary method with International Centrifuge (14000 RPM 51/2 minutes). The serum protein bound iodine (PBI) was estimated by the routine clinical method in the Laboratory of the State Serum Institute, Helsinki.

O r g a n s. The thyroid gland was removed from each experimental animal in the autopsy. The gland was immediately weighed. The relative thyroid weight was calculated in $\mathrm{mg} / 100 \mathrm{~g}$ body weight of the rats. The total weight of the female sex organs (uterus + vagina + ovaries + tubes) and the weight of the testes were also estimated in most cases.

E x p e r i m e n t a 1 d e sign. Experiment I was carried out with 20 adult female rats (Tables $2 \& 3$ ) and 5 adult males. The experiment was repeated with these and 10 additional females (Experiment II) (Table 4). These 30 females have been considered as a first generation. 10 of the females $\left(A_{1}\right)$ were kept on the semisynthetic control diet (Table 1) throughout the experimental period (about 130 days); 10 females $\left(B_{1}\right)$ received a semisynthetic iodine deficient diet during a period of 60 days, and $10\left(\mathrm{C}_{1}\right)$ during a period of 133 days (Table 5). The adult males were used for mating only and they were mostly fed with the commercial mouse and rat diet (Table 1).

The female progeny from the first pregnancy of $A_{1}$, and $C_{1}$, rats were considered as the second generation $\left(A_{2}\right.$ and $C_{2}$ respectively) (Tables $3 \& 5$ ). The $A_{2}$ and $C_{2}$ females were mated at 70 days of age with the above mentioned 5 males and the pups born (third generation) were killed at 25 days of age (Table 3 ).

The male progeny from the first pregnancy (Experiment $I$ ) of the $A_{1}$ and $C_{1}$ rats were killed at 60 days of age (Table 2). Both female and male progeny from the second pregnancy of $A_{1}$ and $C_{1}$ females and those from the first pregnancy of the $B_{1}$ females (Experiment II) were killed at 60 days of age (Table 4 ).

The descendants received the same diet as their dams with the exception of a group of pups born to $B_{1}$ dams in Experiment II, which were transferred into the commercial mouse and rat diet directly after weaning at 30 days of age (Table 4$)$. The $A_{1}, B_{1}$ and $C_{1}$ dams were killed as soon as their pups had been weaned in Experiment II. The $A_{2}$ and $C_{2}$ dams were killed as soon as their pups were killed at 25 days of age (Tables $3 \& 5$ ).

The following indices were used to indicate female fertility a) number of dams conceiving, b) pups dropped days after the start of the mating period, c) number and weight of the pups at birth, d) pup mortality during the suckling period, and e) total weight of the female sex organs. Lactational ability of the rats with pups was investigated by measuring the growth of the pups during the first 15 days after birth. Also the growth performance of the progeny from weaning (at 30 days) up to 60 days of age was investigated.

\section{Results and discussion}

Experimen $\mathrm{t}$ I. The results obtained from Experiment $\mathrm{I}$ have been summarized in Tables $2 \& 3$. The values in Table 2 indicate that the $A_{1}$ rats conceived better, dropped 


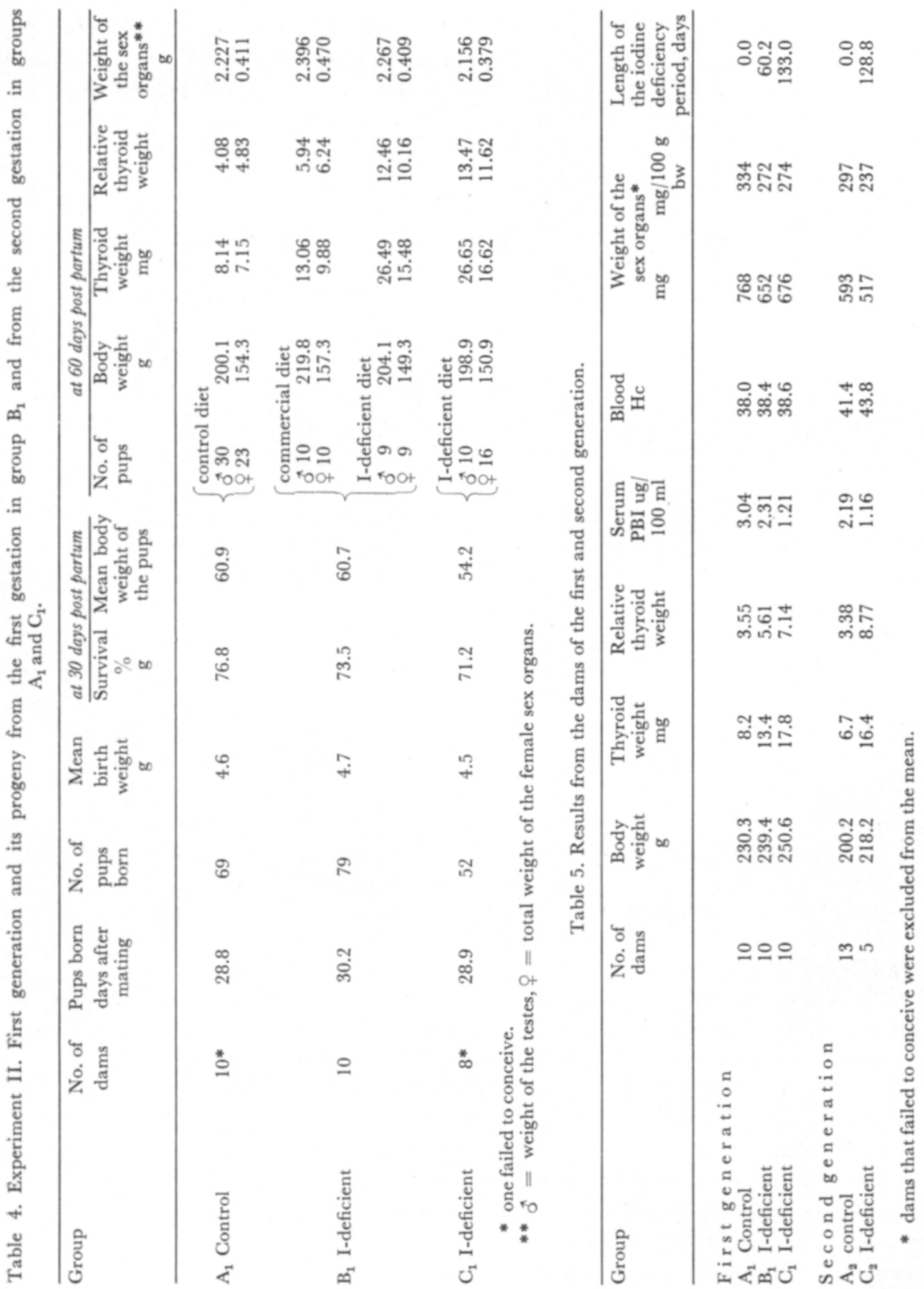

their pups earlier, and had more pups with a heavier birth weight compared to the $\mathrm{C}_{1}$ rats. The differences between the two groups were nonsignificant, however. Survival of pups was 
better in group $A_{1}$. Lactational ability in $\mathrm{C}_{1}$ dams was apparently not impaired at this stage by iodine deficiency since 15-day-old pups of group $\mathrm{C}_{1}$ weighed more $(18.2 \mathrm{~g})$ than those of group $A_{1}(17.0 \mathrm{~g})$. As a whole, the survival of the pups was very poor in both groups due to the unfavourable environment (unsuitable cages and air too dry in the rat room) during the early phase of Experiment $I$; only $31.7 \%$ of the pups in $A_{1}$ and $24.5 \%$ of the pups in $C_{1}$ were alive at 30 days of age (Table 2).

The male progeny of $A_{1}$ and $C_{1}$ rats were killed at 60 days of age (Table 2). The male progeny of $\mathrm{C}_{1}$ rats had significantly heavier mean thyroid weight (16.4 mg) than that of the $A_{1}$ rats $(6.0 \mathrm{mg})$; the body weight and the weight of the testes, in turn, were slightly higher in group $\mathrm{C}_{1}$.

The female progeny $\left(A_{2}\right.$ and $\left.C_{2}\right)$ of $A_{1}$ and $C_{1}$ rats were mated at 70 days of age. $A_{2}$ females dropped their pups significantly sooner than $\mathrm{C}_{2}$ females (Table 3 ). Also the viability of the pups of $A_{2}$ rats was somewhat better compared to group $\mathrm{C}_{2}$ (pups alive at 25 days of age, $76.9 \%$ and $73.4 \%$ respectively). However, the pups were larger in group $\mathrm{C}_{2}$, although their thyroids were more than three times heavier $(13.8 \mathrm{mg})$ as compared to group $\mathrm{A}_{2}(4.1$ $\mathrm{mg})$.

Ex p e r i m e n t II. The experiment was repeated with $10 A_{1}$ and $8 C_{1}$ rats of Experiment I (Table 2) and 10 additional adult females ( $B_{1}$ rats). The results from Experiment II have been summarized in Table 4. One out of the $10 \mathrm{~A}_{1}$ rats, and one out of the $8 \mathrm{C}_{1}$ rats failed to conceive. The number of days from mating to dropping the pups by the dams that conceived was the same in the three groups. The number of pups born and their mean birth weight did not significantly differ between the three groups even though the lowest values were noted in group $\mathrm{C}_{1}$. The growth rate and viability of the pups during the suckling period was the lowest in group $\mathrm{C}_{1}$. The mean body weight of the pups at 15 days after birth was $25.3 \mathrm{~g}$ in $\mathrm{A}_{1}, 24.9 \mathrm{~g}$ in $\mathrm{B}_{1}$ and $21.3 \mathrm{~g}$ in $\mathrm{C}_{1}$, the difference between $\mathrm{A}_{1}$ and $\mathrm{C}_{1}$ being significant. The iodine deficiency had possibly affected unfavourably lactational performance of the $\mathrm{C}_{1}$ dams, which had already had one previous gestation and lactation on the iodine deficient diet. The survival percentage of the pups at weaning was 76.8 in $A_{1}, 73.5$ in $B_{1}$, and 71.2 in $\mathrm{C}_{1}$ (Table 4), which trend was similar to that noted in Experiment I (Tables 2 \& 3). At weaning the mean body weight of the pups was smaller in group $\mathrm{C}_{1}(54.2 \mathrm{~g})$ as compared to $A_{1}(60.9 \mathrm{~g})$ and $B_{1}(60.7 \mathrm{~g})$ rats (Table 4$)$. As a whole the pup viability was better in Experiment II than in Experiment I.

The pups were weaned at 30 days of age. After weaning, 30 ond 23 progeny of the $A_{1}$ rats were fed with the semisynthetic control diet until 60 days of age (Table 4). Respectively, $10 \delta$ and 10 o progeny of the $B_{1}$ rats were transferred from the iodine deficient diet to the commercial mouse and rat diet (Table 1), while their selected litter mates (9 $\delta^{\star}$ and 9 \%) remained on the iodine deficient diet. 10 s and 16 o progeny of the $\mathrm{C}_{1}$ rats remained on the iodine deficient diet until 60 days old. The surplus pups were removed from the experiment.

Results in Table 4 indicate that the progeny of $B_{1}$ rats transferred from the iodine deficient to the commercial diet had the highest mean body weight (o 219.8 and $+157.3 \mathrm{~g}$ ) at 60 days of age. On the other hand, the mean body weight of the progeny of control rats $\left(A_{1}\right)$ did not significantly differ from that of the progeny of the iodine deficient $B_{1}$ and $C_{1}$ rats (Table 4 ).

The results from this phase of the study suggest that an activation of the thyroid, as a result of an iodine deficiency during the early stage of postnatal growth, may actually stimulate growth during a later growth period if the iodine content of the diet is increased. 
The progeny of the $A_{1}$ rats (controls) had the smallest thyroids (ot 8.14 and o $7.15 \mathrm{mg}$ ) (Table 4). The progeny of the $B_{1}$ rats kept on commercial diet after weaning had significantly heavier thyroids ( $\$ 13.06$ and $\$ 9.88 \mathrm{mg}$ ) than the controls, but significantly smaller thyroids than those kept on iodine deficient diet respectively $\left(\mathrm{B}_{1} \delta^{\star} 26.49\right.$ and $+15.48 \mathrm{mg} ; \mathrm{C}_{1}$ o 26.65 and $16.62 \mathrm{mg}$ ). On the other hand, the the thyroid weights in the two latter groups did not significantly differ from each other although the $\mathrm{C}_{1}$ dams had been on the iodine deficient diet much longer than the $\mathrm{B}_{1}$ dams (Table 5). Within the four 60 -day-old rat groups, the absolute thyroid weight was greater in males than females (Table 4). The relative thyroid weight was higher in females kept on control or commercial diet but smaller in those kept on an iodine deficient diet compared to the respective relative thyroid weights of the males. 60 -day-old males were considerably heavier than females. Possibly the more rapid growth of the males tended to exhaust their body iodine stores more quickly while kept on an iodine deficient diet and as a result there was a greater enlargement of the thyroid compared to the females. According to the results in Table 4, iodine deficiency did not seem to impair the growth of young rats after weaning indicating that the iodine stores in their body were still large enough for intensive growth. It should be mentioned, however, that a litter of pups with a very low mean body weight was removed from group $\mathrm{C}_{1}$ during Experiment $\mathrm{II}$ at weaning. Thus it seems that a prolonged iodine deficiency will eventually interfere with growth.

Iodine deficiency appeared to have no significant effect on the weight of the sex organs of the 60-day-old pups. However, the heaviest sex organs were found in rats transferred from iodine deficient to a commercial diet and the lightest in those belonging to group $\mathrm{C}_{\mathbf{1}}$. The trend is similar to that noted in the body weight.

$\mathrm{Results}$ from the da ms. The results obtained from the dams of the first and second generation have been summarized in Table 5 . As seen from Table 5, the body weight of the control rats was somewhat smaller compared to the iodine deficient rats.

In the first generation dams, the thyroid weight increased but the PBI level decreased progressively with increasing length of the iodine deficiency period. The corresponding changes in the second generation dams were linear with those of the first generation. The differences in the thyroid weight between $A_{1}$ and $B_{1}$; between $B_{1}$ and $C_{1}$, and between $A_{2}$ and $\mathrm{C}_{2}$ were highly significant. The differences in the PBI level between $A_{1}$ and $C_{1}$, and between $\mathrm{A}_{2}$ and $\mathrm{C}_{2}$, were also highly significant. On an average, the sex organs were heavier in the control rats than in the iodine deficient ones (Table 5).

\section{Conclusions and summary}

The experimental period was apparently too short and the number of rats too small to demonstrate a significant effect of iodine deficiency on some indices of reproduction of the females and the growth rate of their progeny. It was found, however, that iodine deficiency: a) delayed significantly the conception of the second generation females $\left(\mathrm{C}_{2}\right)$ (Table 3$)$ but was quite ineffective in the first generation females $\left(\mathrm{B}_{1}, \mathrm{C}_{1}\right)$ (Tables 2 \& 4 ), b) did not significantly affect the number of pups dropped or their birth weight, c) increased pup mortality during suckling period, d) tended to decrease the weight of the female sex organs of adult rats (Table 5),e) increased the absolute thyroid weight more rapidly in young growing rats than in old fullgrown rats (Tables 3, 4 \& 5), and more rapidly in growing males than females, 
f) decreased significantly and progressively the PBI level in the serum of adult females which had pregnancies and lactations, g) obviously adversely affected the milk secretion of $\mathrm{C}_{1}$ rats during their second lactation on iodine deficient diet (Experiment II) as judged from the growth rate of their pups during $0-15$ days after birth, h) did not adversely affect the growth rate of the suckling offspring of the dams during their first lactation on iodine deficient diet (Tables $3 \& 4$ ), i) did not significantly affect the rate of gain of the young rats from weaning up to 60-days of age.

The rats transferred from iodine deficient to commercial diet at weaning had larger body weights and smaller thyroids at the age of 60 days than their litter mates remaining on an iodine deficient diet (Table 4). There is of course a possibility that the commercial diet was more palatable than the semisynthetic diet. It is also possible that the iodine deficiency activated the thyroid during the preweaning period and that after the transfer to iodine containing commercial diet at weaning, more thyroxine was secreted from preactivated glands compared to thyroids of the controls or thyroids of the rats kept on an iodine deficident diet throughout the growth period. Thyroid hormones are required for normal growth. A hypothyroid condition favours the accumulation of water and fat into the body tissues and may by this way result in an increase of the body weight.In this study, however, no attempt was made to estimate the fat content of the body of the experimental rats.

\section{REFERENCES}

Astrng, C. W. \& Evans, E. S. 1963. Maintenance of skeletal growth and maturation in thyroidectomized rats by injection of iodide. Endocrin. 72: 283-291.

Eкman, L. 1965. Thyroidectomy of the goat. Acta Physiol. Scand. 65: 331-36.

Evans, E. S., Rosenberg, L. L. \& Stmpson, M. E. 1960. Relative sensitivity of different biological responses to thyroxine. Endocrin. 66: 433-440.

FAlCONER, I. R. 1965. Effect of thyroid deficiency in the ewe on lamb viability. Nature, London $205: 703$.

Flux, D. S., Butler, G. W., Rae, A. L. \& Brougham, R. W. 1960. Relationship between levels of iodine and cyanogenetic glucoside in pasture and the productive performance of sheep. J. Agric. Sci. 55: $191-196$.

Gaunt, R., Chart, J. J. \& Renzy, A. A. 1965. Inhibitors of adrenal cortical function. Ergebn. physiol. Biol. Chem u. Exp. Pharm. 56: 114-172.

Gorbman, A. 1955. The thyroid. Report of Symposium held June 9 to 11, 1954, p. 3. Brookhaven National Laboratory, New York.

- - \& Evans, H. M. 1941. The time of beginning of function in the thyroid glands of fetal rats. Anat. Rec. 81: 95.

Griesbach, W. E., Evans, E. S. \& Chaikoff, I. L. 1963. Does iodide produce a significant regranulation of pituitary acidophils in thyroidectomized rats? Endocrin. 72: $474-479$.

Guilbert, H. R. 1942. Some endocrine relationships in nutritional reproductive failure, a review. J. Anim. Sci. 1: 3.

Hart, D. S. 1960. Fertility responses in ewes treated with thyroxine. N. Z. J. Agric. Res. 3: 565-578.

Hsien, A. C. L. 1962. The role of the thyroid in rats exposed to cold. J. Physiol. 161: 175-188.

Johnson, T. N. \& Mertes, J. 1950. Effects of hypo- and hyperthyroidism in rats and mice on ovarian responce to equine gonadotrophin. Proc. Soc. Exp. Biol. Med. 75: 155.

Jorgensen, E. C. \& Wrley, R. A. 1963. Thyroxine analogs. X. 3.5-diamino-, 3,5-dicyano-, and 3.5-dicarboxy - DL - thyronines. J. Med. Chem. 6: 459-462.

Lamming, G. E. 1966. Nutrition and endocrine systems. Nutr. Abstr. \& Rews 36: 1-13.

Logothetopoulos, J. \& Scott, R. F. 1956. Histology and function of the developing foetal thyroid in normal and goitrous guinea-pigs. J. Endocrin. 14: 217-227. 
Rauen, H. M. ed. 1964. Biochemisches Taschenbuch. Zweiter Teil. 2. Aufl. VIII+1084 S. p. $278,281$. Berlin.

Rogler, J. C. 1958. Effects of iodine on hatchability and embryonic development. Diss. Abstr. 18: 192526. Purdue Univ.

Rogler, J. C., Parker, H. C., Andrews, F. N. \& Carrick, C. W. 1959. Effects of iodine deficiency on embryo development and hatchability. Poultry Sci. 38: 398-405.

RyLE, M. 1961. Early reproductive failure of ewes in a hot environment. 1. Ovulation rate and embryonic mortality. J. Agric. Sci. 57: 1-9.

Schultze, A. B. \& Turner, C. W. 1947. The determination of the rate of thyroxine secretion by certain domestic animals. Univ. Missouri Res. Bull No. 392.

SEPPÄNEN, R. 1969. Studies on the use of tall oil fatty acids in the diet of rats. Ann. Acad. Scient. Fenn. Ser. A II. Chem. 144, 85 pp.

Sethre, A. E. \& Wells, L. J. 1951. Accelerated growth of the thyroid in normal and hypophysectomized fetal rats given thyrotrophin. Endocrin. 49: 369-373.

Soliman, F. A. \& Reineke, E. P. 1952. Influence of variations in environmental temperature and thyroid status on sexual functions in young female mice. Am. J. Physiol. 168: 400.

Tномpson, T. 1933. Influence of the intake of calcium on the thyroid gland of the albino rat. Arch. Path. 16: 211.

Turner, C. W. 1959. California pioneers new method of feeding thyroprotein. Feedstuffs $31: 32-34$.

VAes, G. 1960. Bericht über den Einfluss der Thyreoideafunktion und der jahreszeitlichen Schwankungen auf die Uterusreaktion nach Oestradiolgaben beim Kaninchen. Ann. d'Endocrin. 21: 495-500. Paris.

\title{
SELOSTUS
}

\section{JODINPUUTOKSEN VAIKUTUS NAARASROTTIEN HEDELMÄLLISYYTEEN SEKÄ JÄLKE- LÄISTEN ELINVOIMAISUUTEEN JA KASVUNOPEUTEEN}

\author{
Vappu Kossila ja Ritva Myllymaa \\ Helsingin yliopiston kotieläintieteen laitos
}

Tutkimus suoritettiin 30:lla täysikasvuisella emorotalla (1. polvi) ja näiden jälkeläisillä (2. ja 3. polvi). Rotille syötettiin semisynteettistä dieettiä, mikä muuten oli samanlainen paitsi että jodinpuutosryhmältä jätettiin $\mathrm{KJ}$ pois.

Tutkimuksessa todettiin mm. että jodinpuutosemoilla: a) parittelusta poikimiseen kulunut aika lisääntyi vasta 2. polvessa merkittävästi, b) syntyneiden poikasten lukumäärä ja syntymäpaino olivat samaa suuruusluokkaa kuin kontrolleilla, c) poikaskuolleisuus lisääntyi imettämisaikana, d) poikasten kasvunopeus ei imettämisaikana poikennut kontrolleista ensimmäisen laktaation aikana puutosdieetillä kun taas toisen laktaation aikana oli havaittavissa kasvunopeuden heikentymistä kontrolliin verrattuna, e) kilpirauhaspaino lisääntyi ja veriseerumin proteiiniin sidotun jodin (PBI) määrä laski progressiivisesti jodinpuutoskauden pidentyessä samalla kun sukuelinten painossa oli havaittavissa pienentymistä.

Edelleen todettiin, että jodinpuutosdieetillä a) nuorten rottien kilpirauhaspaino kohosi nopeammin kuin täyskasvuisten ja b) nuorilla koirailla kilpirauhaspaino kohosi nopeammin kuin nuorilla naarailla. Lisäksi havaittiin, että vaikka jodinpuutosrotilla 60 p:n iässä oli noin kolme kertaa suurempi kilpirauhanen kuin kontrolleilla, ei puutos näyttänyt vaikuttaneen käytännöllisesti katsoen vielä lainkaan kasvuun. 